\title{
The Electrical Conductivity of Molten Oxide-Fluoride Cryolite Mixtures
}

\author{
Pavel Arkhipov*(1) and Olga Tkacheva \\ Institute of High Temperature Electrochemistry, Ural Branch of the Russian Academy of Sciences, \\ 620990 Ekaterinburg, Russia; o.tkacheva@ihte.uran.ru \\ * Correspondence: arh@ihte.uran.ru
}

Citation: Arkhipov, P.; Tkacheva, O. The Electrical Conductivity of Molten Oxide-Fluoride Cryolite Mixtures. Materials 2021, 14, 7419. https:// doi.org/10.3390/ma14237419

Academic Editor: Giovanni Battista Appetecchi

Received: 15 October 2021

Accepted: 30 November 2021

Published: 3 December 2021

Publisher's Note: MDPI stays neutral with regard to jurisdictional claims in published maps and institutional affiliations.

Copyright: (c) 2021 by the authors. Licensee MDPI, Basel, Switzerland. This article is an open access article distributed under the terms and conditions of the Creative Commons Attribution (CC BY) license (https:// creativecommons.org/licenses/by/ $4.0 /)$.

\begin{abstract}
A new way to reduce the energy consumption during the operation of powerful aluminum reduction cells is suggested via reducing the resistance of the electrolyte, i.e., increasing its electrical conductivity. The electrical conductivity of molten cryolite mixtures $\mathrm{NaF}-\mathrm{AlF}_{3}-\mathrm{CaF}_{2}-\mathrm{Al}_{2} \mathrm{O}_{3}$ with cryolite ratio (CR) of 2.1-3.0 and content of $\mathrm{CaF}_{2}$ and $\mathrm{Al}_{2} \mathrm{O}_{3}$, up to $8 \mathrm{wt} \%$, was measured at the temperatures from liquidus to $1300 \mathrm{~K}$. Based on the experimental results, a multifunctional equation for the electrical conductivity of oxide-fluoride cryolite melts was evaluated. The experimental and calculated values of the electrical conductivity agree within $1.5 \%$. The activation energy of the electrical conductivity of the $\mathrm{NaF}-\mathrm{AlF}_{3}-\mathrm{CaF}_{2}-\mathrm{Al}_{2} \mathrm{O}_{3}$ melts was estimated. The activation energy of

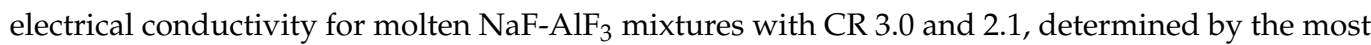
mobile cations $\mathrm{Na}^{+}$, increased from $15.8 \mathrm{~kJ} / \mathrm{mol}$ up to $18.5 \mathrm{~kJ} / \mathrm{mol}$. It was found that $\mathrm{CR}$ had a greater impact on the activation energy than the changes in the $\mathrm{Al}_{2} \mathrm{O}_{3}$ or $\mathrm{CaF}_{2}$ concentrations. Based on the ratio of the activation energies of the electrical conductivity and the viscous flow, the correlation between the electrical conductivity and viscosity of molten cryolite mixtures $\mathrm{NaF}-\mathrm{AlF}_{3}-\mathrm{CaF}_{2}-\mathrm{Al}_{2} \mathrm{O}_{3}$ was illustrated.
\end{abstract}

Keywords: electrical conductivity; cryolite; alumina; calcium fluoride; activation energy

\section{Introduction}

A distinctive feature of the primary aluminum electrolytic production is a high specific power consumption. The average specific power consumption for electrolytic cells with baked anodes is 14,200 kWh/t Al, and for cells with self-baking anodes-from $15,300 \mathrm{kWh} / \mathrm{t} \mathrm{Al}$ (for cells with side current supply) to 16,000 kWh/t (for cells with the upper current lead), and only $40 \%$ of this electricity is consumed directly for the aluminum production; the rest is spent on heating the cell and heat losses [1,2]. In connection with the commissioning of powerful 400-500 kA cells and the constantly ongoing modification of the design of existing electrolyzers, there is a great need to solve the issues related to electrical conductivity, thermal conductivity, hydrodynamic, and diffusion processes [3-5]. The tendency to raise the cells capacity can be clearly seen on the example of the Chinese aluminum industry. Twenty-seven out of thirty-four large aluminum companies in China use Cell technology 400-500 kA. Two companies, China Hongqiao Group and Shanxi NonFerrous Co. Ltd., implement Cell technology 600 kA [6]. The Shandong Xinfa Aluminum and Electricity Group have built three new $660 \mathrm{kA}$ power lines, which are now operating in Liaocheng (Chipin dong province, China). The capacity of the $660 \mathrm{kA}$ aluminum smelter is 1.15 million tons per year [7].

The practical implementation of the obtained results consists of determining the optimal operating modes and design features of electrolysis cells in order to increase their energy efficiency and environmental friendliness. Currently, the work is underway to optimize the thermal characteristics of aluminum cells. Newly proposed principles and models for controlling the thermal characteristics of the cells will improve energy efficiency 
by more than $50 \%[1,8]$. The main ways of reducing the power consumption during the operation of powerful cells include a reduction in the anode-cathode pole-to-pole distance, decrease in the ohmic resistance in the current-carrying parts of the electrolyzer, and decrease in the electrolyte resistance or, in other words, increase in the electrical conductivity. The alumina addition to the electrolytic cell is an important process in the aluminum electrolysis. The existing mathematical models considering the electrolytic cell feeding process are based on the reference data on physical-chemical properties of cryolite-alumina melts and alumina solubility. These models describe the operation of electrolyzers with medium current load (about $160 \mathrm{kA}$ ). However, in powerful electrolyzers exceeding $300 \mathrm{kA}$, the distribution of alumina concentration in the electrolyte, which is determined by the feeding strategy, influences such technological characteristics as current efficiency, frequency of anode effects, and power consumption. The mathematical model for correlation of physical fields (electrical, electromagnetic, and temperature) of the industrial electrolyzer requires experimental data on electrical conductivity and viscosity of the electrolytes depending on the alumina concentration, temperature, and electrolyte composition.

Conventional electrolytes for aluminum production are based on sodium cryolite. The electrical conductivity of individual sodium cryolite $\left(\mathrm{Na}_{3} \mathrm{AlF}_{6} \equiv 3 \mathrm{NaF}-\mathrm{AlF}_{3}\right)$ and its mixtures has been well studied [9]. It is established that the electrical conductivity of sodium cryolite near the melting point is $2.83 \mathrm{~S} \cdot \mathrm{m}^{-1} \cdot 10^{-2}$. The $\mathrm{NaF}_{-} \mathrm{AlF}_{3}$ electrolyte is characterized by the parameter of cryolite ratio $(\mathrm{CR})$, which is expressed by the molar ratio of sodium fluoride to aluminum fluoride $\mathrm{CR}=n_{\mathrm{NaF}} / n_{\mathrm{AlF} 3}$. An industrial electrolysis, as a rule, is performed at the temperatures of $1223 \pm 5 \mathrm{~K}$. A decrease in the liquidus temperature of sodium cryolite is achieved by increasing the $\mathrm{AlF}_{3}$ concentration, as well as by addition of $\mathrm{CaF}_{2}, \mathrm{MgF}_{2}$, and $\mathrm{Al}_{2} \mathrm{O}_{3}$. Therefore, typical $\mathrm{CR}$ of the electrolyte is $2.3 \pm 0.1$. A decrease in the operating temperature allows suppressing the secondary reaction of aluminum dissolution and, hence, increases in the current efficiency. An increase in the $\mathrm{AlF}_{3}$ concentration in the $\mathrm{NaF}-\mathrm{AlF}_{3}$ mixture, i.e., a decrease in $\mathrm{CR}$, causes a decrease both in the electrical conductivity and in the alumina solubility in molten cryolites. A review [10] compares the electrical conductivity of the $\mathrm{NaF}-\mathrm{AlF}_{3}-\mathrm{Al}_{2} \mathrm{O}_{3}$ melt at different $\mathrm{CR}$, ranging from 2.2 to 3.0. It can be noted that the lower $\mathrm{CR}$ leads to the greater discrepancy in the results obtained by different researchers.

The $\mathrm{CaF}_{2}$ additives reduce the electrical conductivity of cryolite melts [11]. The addition of $\mathrm{CaF}_{2}$ increases the viscosity of the electrolyte and decreases its electrical conductivity. A decrease in the electrical conductivity is associated with the appearance of complex ions and a decrease in the number of charge carriers. As CR values decreases, the effect of $\mathrm{CaF}_{2}$ addition on the electrical conductivity of the cryolite melts becomes more significant. It was found [12] that the $\mathrm{CaF}_{2}$ reduced the electrical conductivity of the NaF-AlF 3 melt more when the proportion of $\mathrm{AlF}_{3}$ increased from 10 to $60 \mathrm{wt} \%$, which is explained by the formation of $\mathrm{CaAlF}_{5}$ and $\mathrm{NaCaAlF}_{6}$ compounds.

The research on the electrical conductivity of fluoride cryolite melts is a complex experimental issue. In addition to the general problems, such as the dependence of the electrolyte resistance on the frequency of alternating current, etc., it is also necessary to take into account the high corrosion activity of fluoride melts and the temperatures of the experiment exceeding $1273 \mathrm{~K}$. To perform a more accurate measurement, coulometric cells with a capillary made of insulating material, which provides sufficiently high electrical resistance, are required. For aggressive fluoride melts, the capillary material, as a rule, is boron nitride (BN) [13-15]. However, the $\mathrm{BN}$ has poor wettability, which is why it is necessary to increase the diameter of the capillary and select its size individually for each salt. For example, in works $[9,16,17]$, a tube made of pyrolytic BN was used instead of the capillary.

The most resistant material for a cell designed to measure the electrical conductivity of fluoride melts is platinum. Cells with parallel platinum electrodes have been successfully used by Slovak scientists to measure the electrical conductivity of molten sodium and 
lithium cryolites, and their mixtures, at the temperatures of 1173-1323 K [18]. Cells with parallel electrodes, despite the small value of the constant, in some cases, have real advantages over the capillary cells [14]. The use of cells with parallel electrodes makes it possible (i) to record changes in the electrical conductivity of molten mixtures with the gradual addition of salts or oxides in one experiment; (ii) to measure the electrical conductivity of melts in a wide temperature range, including the temperatures below the liquidus temperature, in the two-phase region; (iii) to work with molten fluoride salts that destroy the capillary material. Usually, tungsten and molybdenum are used as electrodes.

There are several empirical equations that describe the electrical conductivity of molten multicomponent systems based on sodium cryolite, depending on the temperature and concentration of the components [18-23]. The field of application of the equations is limited by the concentration and temperature ranges. The values of the electrical conductivity of the $\mathrm{Na}_{3} \mathrm{AlF}_{6}-\mathrm{AlF}_{3}$ electrolytes with an excess of the $\mathrm{AlF}_{3}$ content (more than $15 \mathrm{wt} \%$ ), calculated using the equations proposed by different authors, vary significantly in the region of high $\mathrm{AlF}_{3}$ concentrations. It is necessary to take into account the fact that, when deriving equations for the electrical conductivity of multicomponent systems, as a rule, the experimental data obtained for binary electrolytes are used. With an increase in the number of melt components and their concentrations, the discrepancy between the calculated values increases.

Thus, despite the possibility of predicting the values of the electrical conductivity for molten fluoride mixtures of various compositions, it is still crucial to obtain experimental results, which gives grounds for developing more and more accurate model calculations.

This work is aimed at:

(i) measuring the electrical conductivity of fluoride-oxide cryolite melts $\mathrm{NaF}_{-} \mathrm{AlF}_{3}-\mathrm{CaF}_{2}-$ $\mathrm{Al}_{2} \mathrm{O}_{3}$ in a wide range of compositions (CR 2.1-3.0, $\mathrm{CaF}_{2}$ and $\mathrm{Al}_{2} \mathrm{O}_{3}$ concentrations ranging from 0 to $8 \mathrm{wt} \%$ ) in the temperature range from liquidus to $1300 \mathrm{~K}$;

(ii) obtaining a multifunctional equation for calculating the electrical conductivity of oxide-fluoride cryolite melts, based on the experimental results;

(iii) estimating the activation energy of electrical conductivity at $1200-1336 \mathrm{~K}$ and considering the relationship between the electrical conductivity and the viscosity of oxide-fluoride melts.

\section{Materials and Methods}

The main component, sodium cryolite $\mathrm{NaF}_{-} \mathrm{AlF}_{3}$, was prepared from individual salts of $\mathrm{AlF}_{3}$ and $\mathrm{NaF}$ (Vekton, CJSC, St. Petersburg, Russia). The required amount of components (depending on $\mathrm{CR}$ ) was placed in a graphite container and was heated according to the following heating mode:

(1) up to $493 \mathrm{~K}$ and exposed for $2 \mathrm{~h}$ to remove moisture;

(2) up to $773 \mathrm{~K}$ and exposed for $2 \mathrm{~h}$ to remove water of crystallization;

(3) up to $1323 \mathrm{~K}$ until the electrolyte is completely melted.

(4) cooling to room temperature.

The chemically pure $\mathrm{CaF}_{2}$ and $\mathrm{Al}_{2} \mathrm{O}_{3}$ components (Vekton, CJSC, St. Petersburg,

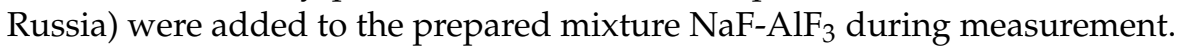

The prepared mixture was analyzed for the content of $\mathrm{Al}, \mathrm{Na}$, and $\mathrm{O}$. The latter was determined using an oxygen analyzer LECO OH 836 (LECO, St. Joseph, MI, USA), which is based on carbothermal oxygen reduction in solid samples. The $\mathrm{Al}$ and $\mathrm{Na}$ concentrations are determined by an ICP-MC device (CiCAP 6300 Duo, Thermo Scientific, Waltham, MA,

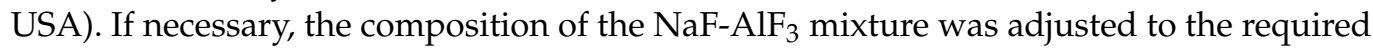
$\mathrm{CR}$ value by adding $\mathrm{AlF}_{3}$.

The electrical conductivity was measured by the electrochemical impedance spectroscopy (EIS) using a PGSTAT AutoLab 302N (Eco Chemie, Metrohm Autolab B.V., Utrecht, The Netherlands) in an electrochemical cell, with two parallel electrodes immersed into the melt. The cell layout is shown in Figure 1. 


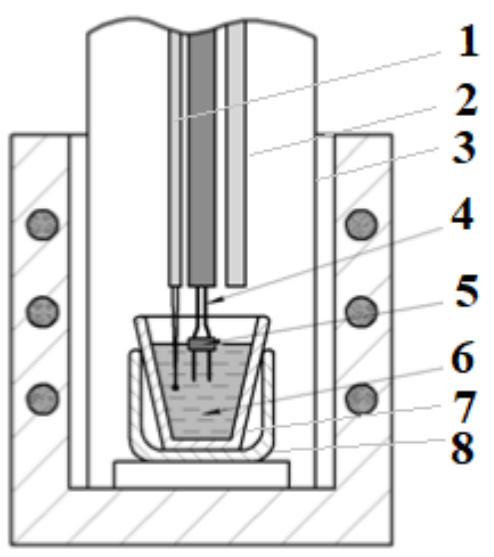

Figure 1. Schematic of cell with parallel electrodes for measuring the electrical conductivity: $1-\mathrm{Pt} / \mathrm{Pt}$ (Rh) thermocouple, 2-additive tube (alumina), 3-quartz container, 4-molybdenum electrodes, 5-BN-bar, 6-melt, 7-glass carbon crucible, 8-supporting guard crucible (alumina).

An argon atmosphere was maintained in the cell. The electrolyte resistance was measured by a PGSTAT AutoLab 302N device (Eco Chemie, Metrohm Autolab B.V., Utrecht, The Netherlands). The procedure is described in detail elsewhere [14]. A distinctive feature of the cell is the use of a boron nitride bar. This bar provided a rigid fixation of the electrodes and a constancy of the surface area of the electrodes in the melt. Thus, a change in the volume of the melt, when adding $\mathrm{CaF}_{2}$ and $\mathrm{Al}_{2} \mathrm{O}_{3}$ during measurements, affected neither the immersion depth of the electrodes, nor the inter electrode distance, which could change due to thermal expansion at the temperatures of about $1323 \mathrm{~K}$.

The melt resistance was determined using the Nyquist plot, according to the value of the active part of the impedance in the point of the X-axis intersection. As an example, Nyquist plots for some melts are shown in Figure 2. Curves 1 and 2 were obtained in the frequency range from 100 to $4 \mathrm{kHz}$, and curves 3 and 4 were obtained at the frequencies ranging from 50 to $4 \mathrm{kHz}$.

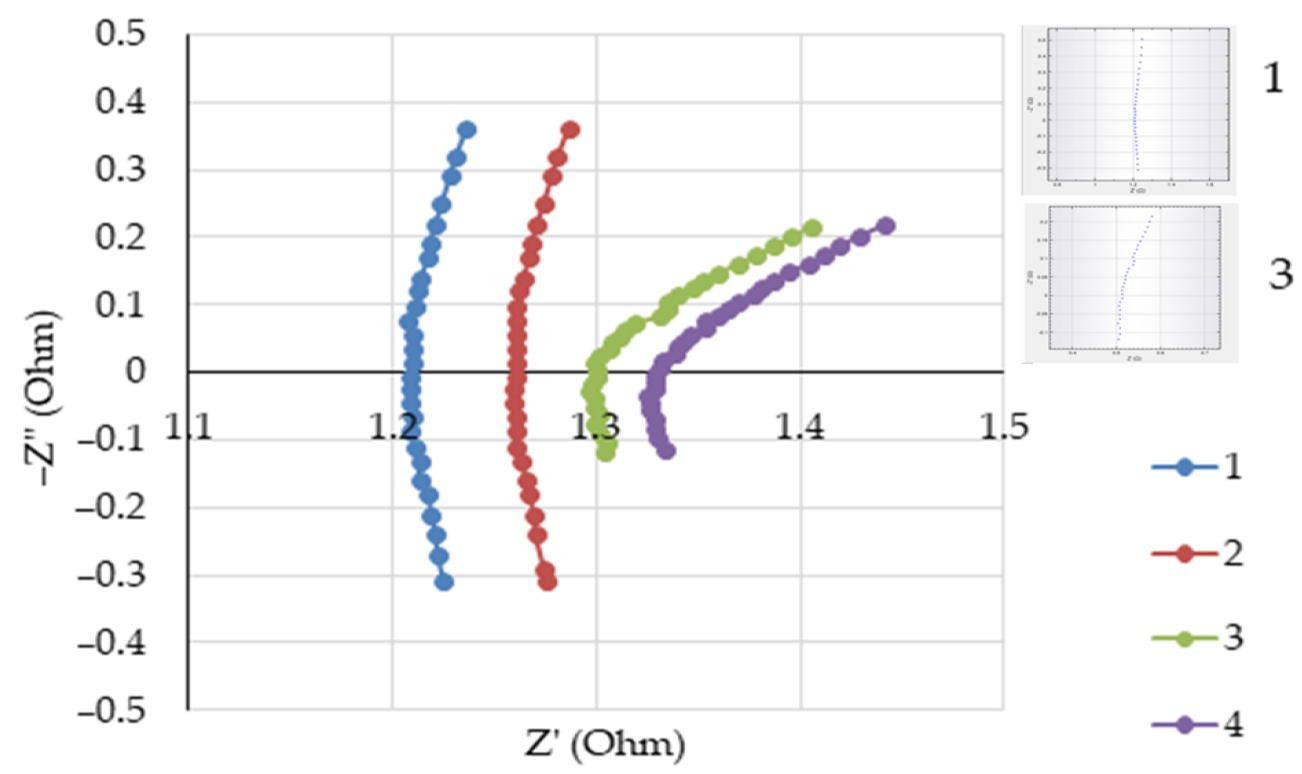

Figure 2. Nyquist plots obtained at $1273 \mathrm{~K}$ in the melts: $1-\mathrm{NaF}-\mathrm{AlF}_{3}(\mathrm{CR}=2.3) ; 2-\mathrm{NaF}^{-\mathrm{AlF}_{3}}$ $(\mathrm{CR}=2.1) ; 3-\mathrm{NaF}_{-} \mathrm{AlF}_{3}(\mathrm{CR}=2.1)+2 \mathrm{wt} \% \mathrm{Al}_{2} \mathrm{O}_{3} ; 4-\mathrm{NaF}_{-} \mathrm{AlF}_{3}(\mathrm{CR}=2.1)+4 \mathrm{wt} \% \mathrm{Al}_{2} \mathrm{O}_{3}$. The Autolab original plots for melts 1 and 3 are embedded. 
The electrical conductivity was calculated according to the formula:

$$
\kappa=K / R
$$

where $\kappa$ is the specific electrical conductivity $\left(\mathrm{S} / \mathrm{m} \cdot 10^{-2}\right), \mathrm{K}$ is the cell constant $\left(1 / \mathrm{m} \cdot 10^{-2}\right)$, and $\mathrm{R}$ is the ohmic resistance of the electrolyte (Ohm).

The cell constant was determined from the known value of the electrical conductivity of the sodium cryolite melt with CR $=3.0$ [9] in the temperature range of 1290-1340 K. The dependence of the constant $(\mathrm{K})$ of the experimental cell, with parallel electrodes on temperature, is described by a linear equation:

$$
\mathrm{K}=1.633+\mathrm{T} \cdot 10^{-3}
$$

where $\mathrm{T}$ is the temperature, $\mathrm{K}$.

When calculating the electrical conductivity, the dependence of the cell constant on temperature was taken into account according to Equation (2). The calculation error (systematic and random) in measuring the electrical conductivity was $5 \%$.

\section{Results and Discussion}

\subsection{Measurement of Electrical Conductivity}

The electrical conductivity was measured in molten mixtures based on sodium cryolite with different $C R$. The $C R$ value was changed from 2.1 to 3.0. The concentrations of $\mathrm{CaF}_{2}$ and $\mathrm{Al}_{2} \mathrm{O}_{3}$ additions varied from 0 to $8 \mathrm{wt} \%$. The measurement temperature changed from $1336 \mathrm{~K}$ (max.) to the temperature of the mixture's liquidus. The liquidus temperature was calculated using the equation given by Solhiem [22]. The electrolyte composition and the measured conductivity at different temperatures are summarized in Supplementary Materials.

The electrical conductivity of all cryolite mixtures decreases with cooling and decreasing $\mathrm{CR}$ (i.e., a decreasing $\mathrm{NaF}$ concentration) and with the increasing content of $\mathrm{CaF}_{2}$ and $\mathrm{Al}_{2} \mathrm{O}_{3}$.

The dependence of the electrical conductivity of cryolite melts on the $\mathrm{CaF}_{2}$ content is shown, in Figure 3, for the $\mathrm{NaF}-\mathrm{AlF}_{3}-\mathrm{CaF}_{2}$ compositions with $\mathrm{CR}=2.1$ and 2.7.

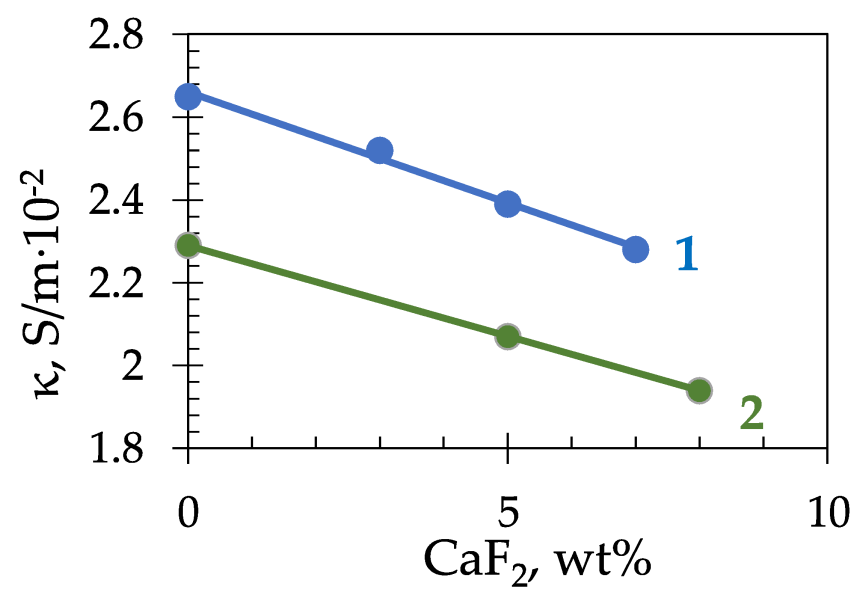

Figure 3. Electrical conductivity of the $\mathrm{NaF}_{-} \mathrm{AlF}_{3}-\mathrm{CaF}_{2}$ melts with $\mathrm{CR}=2.7(1)$ and 2.1 (2) at $1273 \mathrm{~K}$.

Based on the results obtained, it can be concluded that, on average, the addition of

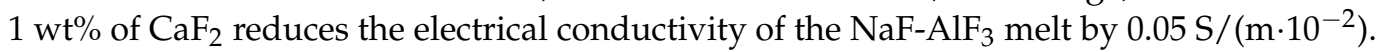

The effect of alumina concentration on the electrical conductivity of cryolite melts can be determined from Figure 4 . This figure includes the results, obtained by calculating and using the regression equations, given in $[18,24]$ for the $\mathrm{NaF}-\mathrm{AlF}_{3}-\mathrm{Al}_{2} \mathrm{O}_{3}$ melts with CR 3.0, 2.4, and 1.8 and the newly obtained experimental data for the molten systems: $\mathrm{NaF}^{-\mathrm{AlF}_{3}}$ with $\mathrm{CR}=2.4$ and $2.1 ; \mathrm{NaF}_{-} \mathrm{AlF}_{3}-(5 \mathrm{wt} \%) \mathrm{CaF}_{2}$ with $\mathrm{CR}=2.1$. 


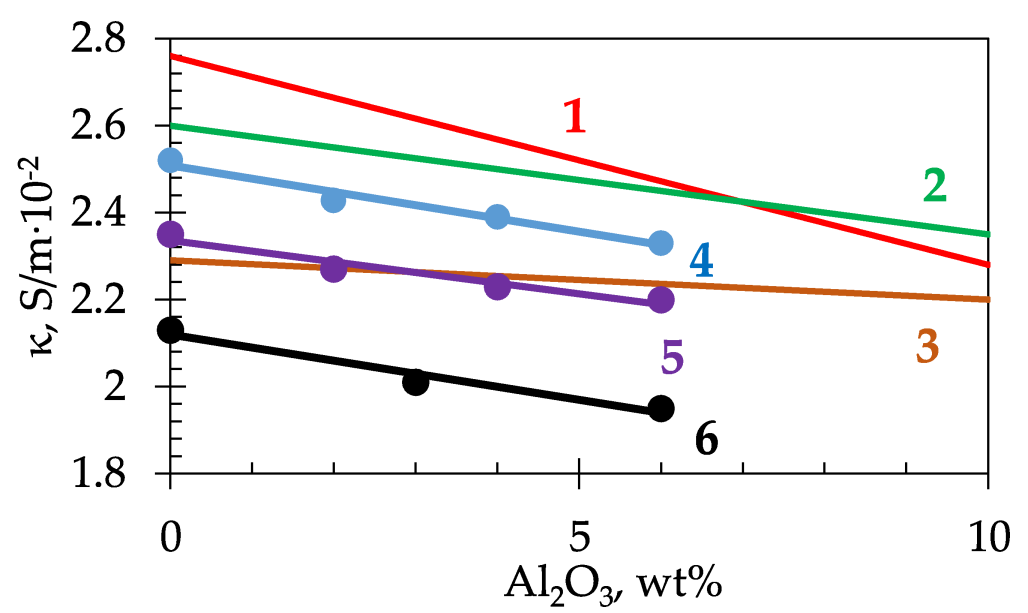

Figure 4. Electrical conductivity of cryolite melts, depending on the alumina concentration at

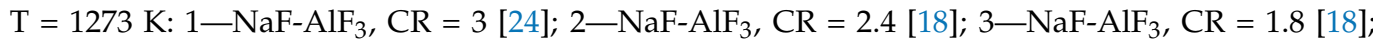
$4-\mathrm{NaF}-\mathrm{AlF}_{3}, \mathrm{CR}=2.4 ; 5-\mathrm{NaF}_{-} \mathrm{AlF}_{3}, \mathrm{CR}=2.1 ; 6-\mathrm{NaF}_{-} \mathrm{AlF}_{3}-(5 \mathrm{wt} \%) \mathrm{CaF}_{2}, \mathrm{CR}=2.1$.

First, it should be noted that the experimental and calculated data, according to the generalized equation [18] for the electrical conductivity, of the $\mathrm{NaF}^{-\mathrm{AlF}_{3}}$ (CR 2.4) melt diverge within $4 \%$.

The alumina additions to the cryolite melts, with any $\mathrm{CR}$, reduce its electrical conductivity, which is associated with the appearance of low-mobile oxide-fluoride complex anions of different compositions. According to papers [18,24], the lower values of CR result in the smaller influence of alumina concentration on the electrical conductivity. For example, for cryolite melts with $\mathrm{CR}=3.0$, the addition of $1 \%$ of $\mathrm{Al}_{2} \mathrm{O}_{3}$ decreases the electrical

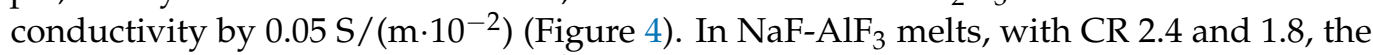
decrease is 0.025 and $0.01 \mathrm{~S} /\left(\mathrm{m} \cdot 10^{-2}\right)$, respectively. The different effect of alumina on the change in the electrical conductivity of the $\mathrm{NaF}-\mathrm{AlF}_{3}$ melts is a consequence of various reactions occurring in neutral and acidic electrolytes during the $\mathrm{Al}_{2} \mathrm{O}_{3}$ dissolution. In neutral cryolite melts $(\mathrm{CR}=3)$ the reaction proceeds as follows:

$$
2 \mathrm{AlF}_{6}{ }^{3-}+2 \mathrm{Al}_{2} \mathrm{O}_{3}=3 \mathrm{Al}_{2} \mathrm{O}_{2} \mathrm{~F}_{4}{ }^{2-}
$$

In the cryolite melts with low $\mathrm{CR}$ the following reactions can occur:

$$
\begin{gathered}
4 \mathrm{AlF}_{6}{ }^{3-}+\mathrm{Al}_{2} \mathrm{O}_{3}=3 \mathrm{Al}_{2} \mathrm{OF}_{6}{ }^{3-}+6 \mathrm{~F}^{-} \\
4 \mathrm{AlF}_{4}{ }^{-}+2 \mathrm{Al}_{2} \mathrm{O}_{3}=3 \mathrm{Al}_{2} \mathrm{O}_{2} \mathrm{~F}_{4}{ }^{3-}+4 \mathrm{~F}^{-}
\end{gathered}
$$

It follows from reactions (4) and (5) that the alumina dissolution in the $\mathrm{NaF}^{-\mathrm{AlF}_{3}}$ cryolites with low CR increases the concentration of fluoride ions in the solution, which contributes to the electrical conductivity increase.

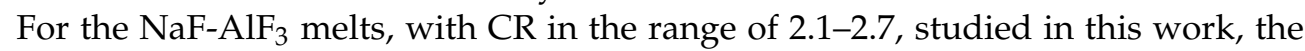
change in electrical conductivity with the addition of $1 \%$ of $\mathrm{Al}_{2} \mathrm{O}_{3}$ is averagely $(0.04-0.05)$ $\mathrm{S} /\left(\mathrm{m} \cdot 10^{-2}\right)$. Thus, no significant difference was observed in the slopes of the straight lines describing the dependence of the electrical conductivity (for cryolites with CR ranging

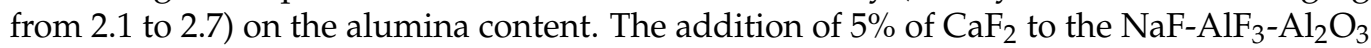
melt with $\mathrm{CR}=2.1$ also had no effect on the curves slope. The results obtained correlate with the data reported by Kubinakova et al. [25], where the decrease in the electrical conductivity of the $\mathrm{NaF}_{-} \mathrm{AlF}_{3}$ system within the $\mathrm{CR}$ range of 1.2-2.0, with the increasing alumina concentration, was about $(0.04-0.06) \mathrm{S} /\left(\mathrm{m} \cdot 10^{-2}\right)$ per $1 \mathrm{wt} \%$ of $\mathrm{Al}_{2} \mathrm{O}_{3}$.

There is another approach to explain the change in the electrical conductivity caused by the alumina addition. Rolin [26] elucidates that the electrical conductivity of sodium cryolite $(\mathrm{CR}=3.0$ and 2.7$)$ decreases as the alumina content increases, due to the higher viscosity of the melt, which is explained by the appearance of complex anions $\left[\mathrm{Al}_{2} \mathrm{OF}_{6}\right]^{2-}$ 
and $\left[\mathrm{Al}_{2} \mathrm{OF}_{8}\right]^{4}$ anions in the melt. The number of these complex anions grows as the alumina concentration in the melt increases.

\subsection{Multifunctional Conductivity Equation}

Experimental data on the electrical conductivity of molten salt mixtures, as a rule, are presented in the form of empirical equations, reflecting its dependence on the concentration and temperature. These dependences can be expressed by both linear and logarithmic equations:

$$
\begin{gathered}
\kappa=A+B T \\
\kappa=A_{\kappa} \cdot \exp \left(-E_{\text {el }} / R T\right)
\end{gathered}
$$

where $\mathrm{K}$ is the specific electrical conductivity, $\mathrm{S} /\left(\mathrm{m} \cdot 10^{-2}\right), \mathrm{A} \kappa$ is the coefficient related to chemical composition of melt; $\mathrm{E}_{\mathrm{el}}$ is the activation energy of the electrical conductivity, $\mathrm{J} / \mathrm{mol}$; $\mathrm{T}$ is the temperature, $\mathrm{K} ; \mathrm{R}$ is the universal gas constant, $8.314 \mathrm{~J} /(\mathrm{mol} \cdot \mathrm{K})$.

These equations are valid in certain concentration and temperature ranges. Nevertheless, it is possible to generalize the electrical conductivity temperature dependence of cryolite mixtures, with different content of components, by one multifunctional equation in wide temperature and concentration ranges. Such calculations were carried out using the Origin program, specially developed for the analysis of experimental data.

The general regression equation for the electrical conductivity of cryolite systems on several parameters was derived by the multivariable data approximation. The data set included the following parameters: temperature, cryolite ratio, calcium fluoride, and alumina content (see Supplementary Materials). The resulting equation has the following form:

$$
\mathrm{K}=-1.87+3.23 \cdot 10^{-3} \cdot \mathrm{T}-2.99 \cdot 10^{-2} \cdot \mathrm{C}\left(\mathrm{Al}_{2} \mathrm{O}_{3}\right)+4.70 \cdot 10^{-1} \cdot \mathrm{CR}-4.37 \cdot 10^{-2} \cdot \mathrm{C}\left(\mathrm{CaF}_{2}\right)
$$

where $\mathrm{K}$ is the electrical conductivity, $\mathrm{S} /\left(\mathrm{m} \cdot 10^{-2}\right)$, $\mathrm{T}$ is the temperature, $(1200-1336 \mathrm{~K})$, $\mathrm{CR}$ is the cryolite ratio, $\mathrm{C}\left(\mathrm{CaF}_{2}\right)$ and $\mathrm{C}\left(\mathrm{Al}_{2} \mathrm{O}_{3}\right)$ are the concentrations of additives, $\mathrm{wt} \%$. Approximation reliability $\mathrm{R}^{2}=0.97$ at the temperatures ranging from $1200 \mathrm{~K}$ to $1336 \mathrm{~K}$.

As an example, the experimental and calculated, by Equation (8) values of the electrical conductivity of oxide-fluoride NaF- $\mathrm{AlF}_{3}-\mathrm{CaF}_{2}-\mathrm{Al}_{2} \mathrm{O}_{3}$ melts, are plotted in Figure 5 .

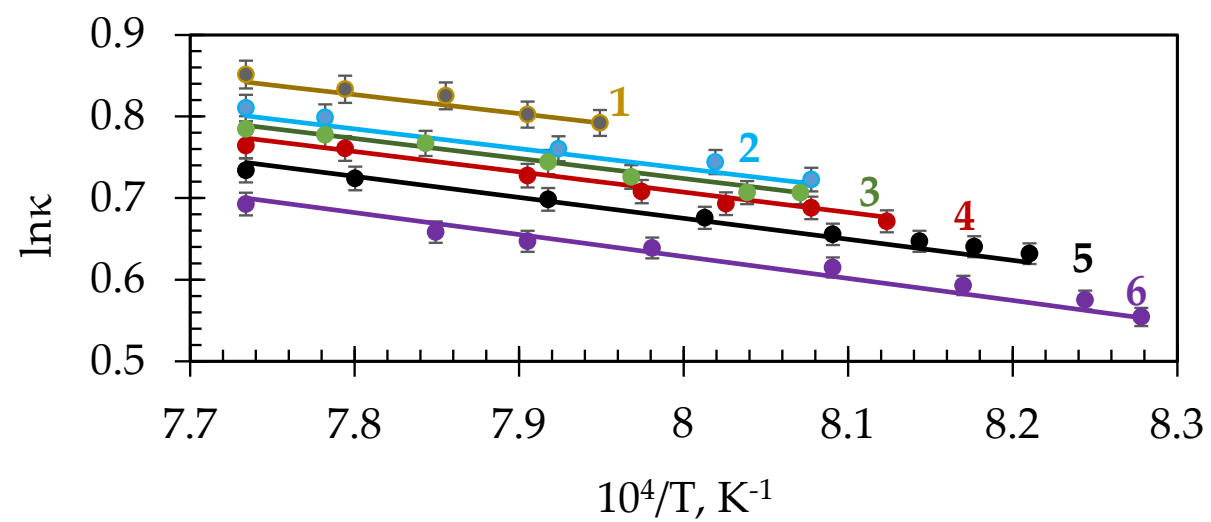

Figure 5. Electrical conductivity of cryolite melts: points denote experimental results, lines denote calculation results (Equation (8)) (wt\%): $1-\mathrm{NaF}_{-} \mathrm{AlF}_{3} \mathrm{CR}=2.5, \mathrm{C}\left(\mathrm{Al}_{2} \mathrm{O}_{3}\right)=2, \mathrm{C}\left(\mathrm{CaF}_{2}\right)=5 ; 2-\mathrm{CR}=2.3$, $\mathrm{C}\left(\mathrm{Al}_{2} \mathrm{O}_{3}\right)=2, \mathrm{C}\left(\mathrm{CaF}_{2}\right)=5 ; 3-\mathrm{CR}=2.5, \mathrm{C}\left(\mathrm{Al}_{2} \mathrm{O}_{3}\right)=6, \mathrm{C}\left(\mathrm{CaF}_{2}\right)=5 ; 4-\mathrm{CR}=2.3, \mathrm{C}\left(\mathrm{Al}_{2} \mathrm{O}_{3}\right)=4$, $\mathrm{C}\left(\mathrm{CaF}_{2}\right)=5 ; 5-\mathrm{CR}=2.1, \mathrm{C}\left(\mathrm{Al}_{2} \mathrm{O}_{3}\right)=3, \mathrm{C}\left(\mathrm{CaF}_{2}\right)=5 ; 6-\mathrm{CR}=2.1, \mathrm{C}\left(\mathrm{Al}_{2} \mathrm{O}_{3}\right)=6, \mathrm{C}\left(\mathrm{CaF}_{2}\right)=5$.

The calculated electrical conductivity is presented as solid lines, and the experimentally obtained values of electrical conductivity are illustrated in the form of points. The experimental and calculated values of the electrical conductivity agree within $1.5 \%$. 


\subsection{Activation Energy of Electrical Conductivity}

The electrical conductivity of cryolite melts in coordinates $\ln \kappa-f(\mathrm{~T})$ is described by the following equation:

$$
\ln \kappa=\mathrm{A}+\mathrm{B} / \mathrm{T}
$$

The values of A and B coefficients of Equation (9), for some compositions of cryolite mixtures, and the calculated activation energy of the electrical conductivity are presented in Table 1.

Table 1. Coefficients $A$ and $B$ for $\ln \kappa=A+B / T$ and the activation energy of the electrical conductivity of cryolite melts.

\begin{tabular}{|c|c|c|c|c|c|}
\hline & A & $-\mathrm{B}, \mathrm{K}^{-1}$ & $\mathbf{R}^{2}$ & $\mathrm{E}_{\mathrm{el}}, \mathrm{kJ} / \mathrm{mol}$ & $\mathrm{T}_{\mathrm{liq}}-\mathrm{T}, \mathrm{K}$ \\
\hline \multicolumn{6}{|c|}{$\mathrm{NaF}^{-\mathrm{AlF}_{3}}$} \\
\hline \multicolumn{6}{|l|}{ CR } \\
\hline 3.0 & 2.5123 & 1901 & 99.8 & 15.8 & $1281-1336$ \\
\hline 2.5 & 2.5546 & 2068 & 99.9 & 17.2 & $1277-1293$ \\
\hline 2.3 & 2.5747 & 2142 & 99.8 & 17.8 & $1258-1293$ \\
\hline 2.1 & 2.6001 & 2224 & 99.8 & 18.5 & $1244-1293$ \\
\hline \multicolumn{6}{|c|}{ 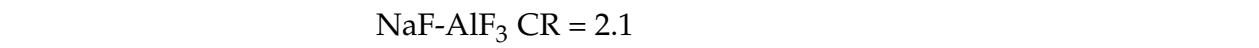 } \\
\hline \multicolumn{6}{|c|}{$\mathrm{Al}_{2} \mathrm{O}_{3}$} \\
\hline 2 & 2.6224 & 2285 & 99.9 & 19.0 & $1222-1293$ \\
\hline 4 & 2.6448 & 2347 & 99.8 & 19.5 & $1210-1293$ \\
\hline 6 & 2.6693 & 2413 & 99.8 & 20.0 & 1200-1293 \\
\hline \multicolumn{6}{|c|}{ 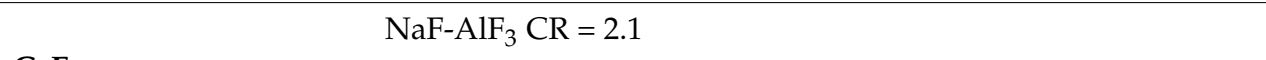 } \\
\hline $\mathrm{CaF}_{2}$ & & & & & \\
\hline 5 & 2.7148 & 2531 & 99.8 & 21.0 & $1228-1293$ \\
\hline 8 & 2.7863 & 2705 & 99.8 & 22.5 & $1225-1293$ \\
\hline
\end{tabular}

The molten cryolite NaF- $\mathrm{AlF}_{3}$ systems are ionic melts; their main structural elements are cations $\mathrm{Na}^{+}$and complex anions $\mathrm{AlF}_{6}{ }^{3-}, \mathrm{AlF}_{5}{ }^{2-}, \mathrm{AlF}_{4}{ }^{-}[27,28]$. The electrical conductivity of these melts is determined by the most mobile $\mathrm{Na}^{+}$cations. With a decrease in the concentration of sodium cations in the melt, i.e., with CR decrease, the electrical conductivity drops abruptly and, accordingly, the activation energy of this process rises. The additions of $\mathrm{Al}_{2} \mathrm{O}_{3}$ and $\mathrm{CaF}_{2}$ also increase the activation energy of the electrical conductivity, due to the formation of complex anions during their dissolution, which impede the charge transfer process. Evaluating $\mathrm{E}_{\mathrm{el}}$ (Table 1), one can conclude that, for the considered range of $\mathrm{Al}_{2} \mathrm{O}_{3}$ or $\mathrm{CaF}_{2}$ concentrations, $\mathrm{CR}$ has a greater impact on $\mathrm{E}_{\mathrm{el}}$ than the $\mathrm{Al}_{2} \mathrm{O}_{3}$ or $\mathrm{CaF}_{2}$ concentrations changes. The $\mathrm{E}_{\mathrm{el}}$, values of molten $\mathrm{NaF}-\mathrm{AlF}_{3}$ increases from $15.8 \mathrm{~kJ} / \mathrm{mol}$ at $\mathrm{CR}=3$ to $18.5 \mathrm{~kJ} / \mathrm{mol}$ at $\mathrm{CR}=2.1$. The aforesaid illustrates the structural changes in the molten $\mathrm{NaF}-\mathrm{AlF}_{3}$ fluoride system, i.e., the number of mobile $\mathrm{Na}^{+}$ions decreases and the number of $\mathrm{AlF}_{6}{ }^{3-}, \mathrm{AlF}_{5}{ }^{2-}, \mathrm{AlF}_{4}{ }^{-}$complex anions increases. The increasing $\mathrm{Al}_{2} \mathrm{O}_{3}$ and $\mathrm{CaF}_{2}$ concentrations decrease the electrical conductivity under otherwise equal conditions. The values of the activation energy of electrical conductivity of molten $\mathrm{NaF}-\mathrm{AlF}_{3}$ increase to $20.0 \mathrm{~kJ} / \mathrm{mol}$ at $6 \mathrm{wt} . \%$ of $\mathrm{Al}_{2} \mathrm{O}_{3}$ and up to $22.5 \mathrm{~kJ} / \mathrm{mol}$ at $8 \mathrm{wt} . \%$ of $\mathrm{CaF}_{2}$. Comparing the $\mathrm{E}_{\mathrm{el}}$ values presented in Table 1, we may conclude that, within the analyzed range of changes in the molten salt compositions, the value of $C R$, i.e., decrease in the $\mathrm{NaF}$ in the melt, has the greatest impact has the greatest impact on the $\mathrm{E}_{\mathrm{el}}$ value.

On the other hand, transport properties, such as the melt viscosity, also change exponentially with temperature:

$$
\eta=A \eta \cdot \exp \left(E_{\mathrm{vis}} / \mathrm{RT}\right)
$$


However, the viscosity is determined by the mobility of complex anions. Even though the mechanism of the electrical conductivity and the viscous fluid flow are different, there is a certain relationship between them. The relationship between the electrical conductivity and the viscosity for molten salts was proposed by Frenkel [29]:

$$
\kappa^{\mathrm{n}} \cdot \eta=\text { Const }
$$

where $n=\mathrm{E}_{\mathrm{vis}} / \mathrm{E}_{\mathrm{el}}$.

Here $\eta$ is the dynamic viscosity $\left(\left(\mathrm{Pa} \cdot 10^{-3}\right) \cdot \mathrm{s}\right), \kappa$ is the electrical conductivity $\left(\mathrm{S} /\left(\mathrm{m} \cdot 10^{-2}\right)\right)$, and $\mathrm{E}_{\mathrm{vis}}$ is the activation energy of the viscous flow $(\mathrm{kJ} / \mathrm{mol})$.

The activation energy of viscosity for some oxide-fluoride cryolite melts is given in Table 2. It was calculated using the equation for the viscosity proposed in our papers [30,31]:

$$
\begin{aligned}
\eta= & 71.75-1.33 \cdot 10^{-1} \cdot(\mathrm{T}-273)-8.21 \cdot 10^{-3} \cdot \mathrm{C}\left(\mathrm{Al}_{2} \mathrm{O}_{3}\right)+3.33 \cdot 10^{-1} \cdot \mathrm{CR}+0.0796 \cdot \mathrm{C}\left(\mathrm{CaF}_{2}\right) \\
& -0.625 \cdot 10^{-5} \cdot \mathrm{T}^{2}-2.08 \cdot\left(\left(\mathrm{C}\left(\mathrm{CaF}_{2}\right)+\mathrm{C}\left(\mathrm{Al}_{2} \mathrm{O}_{3}\right)\right) / \mathrm{C}\left(\mathrm{Al}_{2} \mathrm{O}_{3}\right)^{1.5}+8.12 \cdot 10^{-5} \cdot \mathrm{C}\left(\mathrm{Al}_{2} \mathrm{O}_{3}\right)^{3}\right.
\end{aligned}
$$

where $\mathrm{T}$ is the temperature $(\mathrm{K}), \mathrm{C}\left(\mathrm{Al}_{2} \mathrm{O}_{3}\right)$, and $\mathrm{C}\left(\mathrm{CaF}_{2}\right)$ are the concentrations of components $(\mathrm{wt} \%)$, the $\mathrm{CR}$ is the cryolite ratio. The equation is true in the temperature range from the liquidus to $1300 \mathrm{~K}, \mathrm{CR}$ ranges from 2.1 to 2.5 , the $\mathrm{Al}_{2} \mathrm{O}_{3}$ and $\mathrm{CaF}_{2}$ content is up to 6

\begin{tabular}{|c|c|c|c|c|}
\hline & $\mathrm{T}, \mathrm{K}$ & $\kappa, S /\left(m \cdot 10^{-2}\right)$ & $\eta,\left(\mathrm{Pa} \cdot 10^{3}\right) \cdot \mathrm{s}$ & $\kappa^{n} \cdot \eta$ \\
\hline $\begin{array}{l}1 \\
2 \\
3 \\
4\end{array}$ & $\begin{array}{l}1293 \\
1383 \\
1273 \\
1263\end{array}$ & $\begin{array}{c}\mathrm{R}=2.3, \mathrm{E}_{\mathrm{el}}=17 . \\
2.51 \\
2.48 \\
2.45 \\
2.41\end{array}$ & $\begin{array}{c}\mathrm{E}_{\mathrm{vis}}=41.94 \mathrm{~kJ} / \\
2.38 \\
2.44 \\
2.51 \\
2.59\end{array}$ & $\begin{array}{l}20.8 \\
20.8 \\
20.7 \\
20.6\end{array}$ \\
\hline $\begin{array}{c}5 \\
6 \\
7 \\
8 \\
9 \\
10\end{array}$ & $\begin{array}{l}1293 \\
1283 \\
1273 \\
1263 \\
1253 \\
1243\end{array}$ & $\begin{array}{c}\mathrm{R}=2.1, \mathrm{E}_{\mathrm{el}}=18 . \\
2.41 \\
2.38 \\
2.35 \\
2.31 \\
2.28 \\
2.25\end{array}$ & $\begin{array}{c}\mathrm{E}_{\mathrm{vis}}=45.08 \mathrm{~kJ} / \\
2.32 \\
2.38 \\
2.45 \\
2.53 \\
2.62 \\
2.73\end{array}$ & $\begin{array}{l}19.9 \\
19.7 \\
19.6 \\
19.6 \\
19.7 \\
19.7\end{array}$ \\
\hline $\begin{array}{l}11 \\
12 \\
13 \\
14 \\
15 \\
16 \\
17\end{array}$ & $\begin{array}{l}\mathrm{NaF}- \\
1293 \\
1383 \\
1273 \\
1263 \\
1253 \\
1243 \\
1233\end{array}$ & $\begin{array}{c}\mathrm{Al}_{2} \mathrm{O}_{3}=2 \mathrm{wt} \% \\
2.35 \\
2.32 \\
2.29 \\
2.25 \\
2.22 \\
2.19 \\
2.16\end{array}$ & $\begin{array}{c}\mathrm{kJ} / \mathrm{mol}_{2} \mathrm{E}_{\mathrm{vis}}=4 \\
2.26 \\
2.31 \\
2.38 \\
2.46 \\
2.55 \\
2.66 \\
2.78\end{array}$ & $\begin{array}{l}2.42 \\
18.1 \\
17.9 \\
17.8 \\
17.8 \\
17.8 \\
17.9 \\
18.0\end{array}$ \\
\hline \multicolumn{5}{|c|}{$\begin{array}{lccc}\mathrm{NaF}-\mathrm{AlF}_{3}, \mathrm{CR}=2.1, \mathrm{Al}_{2} \mathrm{O}_{3}=4 \mathrm{wt} \%, \mathrm{E}_{\mathrm{el}}=19.50 \mathrm{~kJ} / \mathrm{mol}, \mathrm{E}_{\mathrm{vis}}=46.33 \mathrm{~kJ} / \mathrm{mol}, n=2.38 \\
1293 & 2.29 & 2.26 & 16.2 \\
1283 & 2.26 & 2.31 & 16.1 \\
1273 & 2.23 & 2.38 & 16.0 \\
1263 & 2.20 & 2.46 & 16.0 \\
1253 & 2.16 & 2.55 & 16.0 \\
1243 & 2.13 & 2.66 & 16.1 \\
1233 & 2.10 & 2.78 & 16.2\end{array}$} \\
\hline $\begin{array}{l}25 \\
26 \\
27 \\
28 \\
29 \\
30 \\
31\end{array}$ & $\begin{array}{r}\mathrm{AlF}_{3} \mathrm{C} \\
1293 \\
1283 \\
1273 \\
1263 \\
1253 \\
1243 \\
1233\end{array}$ & $\begin{aligned} & \mathrm{wt} \% \\
& \mathrm{Al}_{2} \mathrm{O}_{3}= \\
& 2.13 \\
& 2.10 \\
& 2.07 \\
& 2.04 \\
& 2.00 \\
& 1.97 \\
& 1.94\end{aligned}$ & $\begin{array}{l}=21.03 \mathrm{~kJ} / \mathrm{mol}, \\
\quad 2.52 \\
\quad 2.60 \\
2.67 \\
2.75 \\
2.84 \\
2.95 \\
3.07\end{array}$ & $\begin{array}{c}\text { nol, } n=2.39 \\
15.4 \\
15.3 \\
15.2 \\
15.0 \\
15.0 \\
14.9 \\
14.9\end{array}$ \\
\hline
\end{tabular}
and $8 \mathrm{wt} \%$, respectively.

Table 2. Relationship between the electrical conductivity and the viscosity of cryolite melts.

Uncertainties $(\mathrm{u})$ are equal to $u(T)=0.5 \mathrm{~K}, \mathrm{u}(\mathrm{K})=0.01 \mathrm{~S} /\left(\mathrm{m} \cdot 10^{-2}\right), \mathrm{u}(\eta)=0.01 \cdot 10^{-3} \mathrm{~Pa} \cdot \mathrm{s}$. 
A decrease in the $\mathrm{CR}$ of the $\mathrm{NaF}-\mathrm{AlF}_{3}$ system, and the addition of the $\mathrm{Al}_{2} \mathrm{O}_{3}$ and $\mathrm{CaF}_{2}$ to the melt, lead to an increase in the activation energy of the viscous flow.

The ratios between the electrical conductivity and the dynamic viscosity, calculated according to Equation (11), for some cryolite compositions are presented in Table 2.

Table 2 elucidates that, for the illustrated composition of the molten mixtures, the experimentally obtained values of electrical conductivity increase as the temperature increases, and the values of viscosity, calculated for the identical conditions, decrease as the temperature increases. The activation energy of the electrical conductivity increases as $\mathrm{CR}$ increases, and $\mathrm{Al}_{2} \mathrm{O}_{3}$ and $\mathrm{CaF}_{2}$ are added to the electrolyte. The activation energy of viscous flow increases as the $\mathrm{CR}, \mathrm{Al}_{2} \mathrm{O}_{3}$, and $\mathrm{CaF}_{2}$ concentrations increase. The ratio $(n)$ of the activation energy of viscous flow to the electrical conductivity activation energy is greater than unity because the electrical transfer is performed by the ions of smaller size, and the viscous flow is determined by the particles of the larger size. The product of $\left(\kappa^{n} \cdot \eta\right)$ is a constant for a given melt composition and does not depend on temperature. This fact testifies the ionic nature of the melt.

\section{Conclusions}

The experimental study of the electrical conductivity of the fluoride-oxide cryolite mixtures $\mathrm{NaF}-\mathrm{AlF}_{3}-\mathrm{CaF}_{2}-\mathrm{Al}_{2} \mathrm{O}_{3}$ was carried out in a wide range of $\mathrm{CaF}_{2}$ and $\mathrm{Al}_{2} \mathrm{O}_{3}$ compositions $(0-8 \mathrm{wt} \%)$ and $\mathrm{CR}$ ranging from 2.1 to 3.0 in the temperature range from liquidus to $1300 \mathrm{~K}$. A multifunctional equation for calculating the electrical conductivity of oxidefluoride melts based on sodium cryolite was evaluated.

The electrical conductivity of the molten $\mathrm{NaF}-\mathrm{AlF}_{3}$ system was found to increase as the temperature and the cryolite ratio increased, whereas the content of alumina and calcium fluoride decreased.

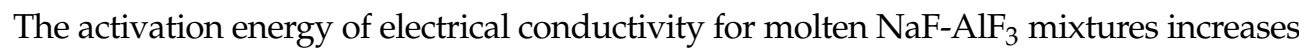
from $15.8 \mathrm{~kJ} / \mathrm{mol}$ (at $\mathrm{CR}=3$ ) up to $18.5 \mathrm{~kJ} / \mathrm{mol}$ (at $\mathrm{CR}=2.1$ ). This indicates the structural changes in the molten fluoride system towards a decrease in the number of mobile cations $\mathrm{Na}^{+}$, and an increase in the content of complex anions $\mathrm{AlF}_{6}{ }^{3-}, \mathrm{AlF}_{5}{ }^{2-}, \mathrm{AlF}_{4}{ }^{-}$.

An increase in the content of $\mathrm{CaF}_{2}$ and $\mathrm{Al}_{2} \mathrm{O}_{3}$ decreases the electrical conductivity, under otherwise equal conditions. The activation energy of electrical conductivity of molten $\mathrm{NaF}-\mathrm{AlF}_{3}-\mathrm{CaF}_{2}-\mathrm{Al}_{2} \mathrm{O}_{3}$ mixtures increases to $20.0 \mathrm{~kJ} / \mathrm{mol}\left(\right.$ at $6 \mathrm{wt} \%$ of $\mathrm{Al}_{2} \mathrm{O}_{3}$ ) and up to $22.5 \mathrm{~kJ} / \mathrm{mol}$ (at $8 \mathrm{wt} \%$ of $\mathrm{CaF}_{2}$ ). Electrical conductivity depends more on the $\mathrm{CaF}_{2}$ content than on alumina at the same temperature and cryolite ratio.

Based on the ratio of the activation energies of the electrical conductivity and the viscous flow, the correlation between the electrical conductivity and viscosity of molten cryolite mixtures $\mathrm{NaF}-\mathrm{AlF}_{3}-\mathrm{CaF}_{2}-\mathrm{Al}_{2} \mathrm{O}_{3}$ was illustrated.

Supplementary Materials: The following are available online at https:/ /www.mdpi.com/article/10 $.3390 / \mathrm{ma14237419/s1}$, Table S1: Composition and the electrical conductivity of the $\mathrm{NaF}_{-} \mathrm{AlF}_{3}-\mathrm{CaF}_{2}-$ $\mathrm{Al}_{2} \mathrm{O}_{3}$ melts.

Author Contributions: Conceptualization O.T. and P.A.; methodology, O.T. and P.A.; validation, P.A.; investigation, O.T. and P.A.; data curation, P.A. and O.T.; writing - original draft preparation, O.T. and P.A.; visualization, O.T. supervision, O.T. and P.A. All authors have read and agreed to the published version of the manuscript.

Funding: This research received no external funding.

Institutional Review Board Statement: Not applicable.

Informed Consent Statement: Not applicable.

Data Availability Statement: All data are freely available.

Acknowledgments: The research was partially performed using the facilities of the Shared Access Centre "Composition of Compounds".

Conflicts of Interest: The authors declare no conflict of interest. 


\section{References}

1. Gorlanov, E.S.; Brichkin, V.N.; Polyakov, A.A. Electrolytic production of aluminium. Review. Part 1. Conventional areas of development. Tsvetnye Metally 2020, 2, 36-41. [CrossRef]

2. Gorlanov, E.S.; Kawalla, R.; Polyakov, A.A. Electrolytic production of aluminium. Review. Part 2. Development Prospects. Tsvetnye Metally 2020, 10, 42-48. [CrossRef]

3. Dingxiong, L.; Yungang, B.; Junman, Q.; Zijin, A. New progress on application of NEIU400kA family high energy efficiency aluminium reduction pot «HEEP» technology. In Light Metals; Lindsay, S.J., Ed.; Springer: Berlin, Germany, $2011 ;$ pp. $443-452$.

4. Thibeault, P.; Mezin, H.; Martin, O. Rio Tinto AP44 cell technology development at ALMA smelter. In Light Metals; Williams, E., Ed.; Springer: Berlin, Germany, 2016; pp. 295-300.

5. Meijer, M. New logistic concept for 400 and 500 kA smelters. In Light Metals; Johnson, J.A., Ed.; Wiley: Chichester, UK, 2010; pp. 343-348.

6. Gao, B.; Wang, Z.; Shi, Z.; Hu, X. History and recent developments in aluminum smelting in China. Travaux 46. In Proceedings of the 35th International ICSOBA Conference, Hamburg, Germany, 2-5 October 2017; pp. 53-68.

7. Tabereaux, A. Super-high amperage prebake cell technologies in operation at worldwide aluminum smelters. Light Met. Age 2017, $75,30-32$.

8. Liang, X. Optimization of thermal characteristics and "Output side energy saving" of aluminum reduction cell. In Light Metals; Perander, L., Ed.; Springer: Berlin, Germany, 2021; pp. 325-332. [CrossRef]

9. Hives, J.; Thonstad, J.; Sterten, A.; Fellner, P. Electrical conductivity of molten cryolite-based mixtures obtained with a tube-type cell made of pyrolytic boron nitride. Metall. Mater. Trans. B 1996, 27, 255-261. [CrossRef]

10. Cassayre, L.; Palau, P.; Chamelot, P.; Massot, L. Properties of low-temperature melting electrolytes for the aluminum electrolysis process: A review. J. Chem. Eng. Data 2010, 55, 4549-4560. [CrossRef]

11. Fellner, P.; Midtlyng, S.; Sterten, A.; Thonstad, J. Electrical conductivity of low melting baths for aluminium electrolysis: The system $\mathrm{Na}_{3} \mathrm{AlF}_{6}-\mathrm{Li}_{3} \mathrm{AlF}_{6}-\mathrm{AlF}_{3}$ and the influence of additions of $\mathrm{Al}_{2} \mathrm{O}_{3}, \mathrm{CaF}_{2}$ and $\mathrm{MgF}_{2}$. J. Appl. Electrochem. 1993, 23, 78-81. [CrossRef]

12. Dedyukhin, A.; Tkacheva, O.; Redkin, A.; Zaikov, Y. Calcium Fluoride Effect on the Physical-Chemical Properties of Cryolites Prospective for Low-Temperature Aluminum Electrolysis, Proceedings of the AIP Conference, St. Petersburg, Russia, 19-21 May 2017; Polyakova, M., Ed.; AIP: College Park, MD, USA, 2017; Volume 1858, p. 030002. [CrossRef]

13. Moran, E. Boron Nitride: Properties, Synthesis and Applications; Nova Science Publishers Inc.: Hauppauge, NY, USA, 2017; 255p.

14. Kryukovsky, V.A.; Frolov, A.V.; Tkacheva, O.Y.; Redkin, A.A.; Zaikov, Y.P.; Khokhlov, V.A.; Apisarov, A.P. Electrical Conductivity of Low Melting Cryolite Melts, Proceedings of the 135th TMS Annual Meeting, San Antonio, TX, USA, 12-16 March 2006; Galloway, T.J., Ed.; TMS: Warrendale, PA, USA, 2006; Volume 1, pp. 409-413.

15. Palimaka, P.; Pietrzyk, S.; Sak, T. Application of CVCC technique for measuring electrical conductivity of metallurgical slags and molten salts. Key Eng. Mater. 2016, 682, 321-326. [CrossRef]

16. Huang, Y.; Lai, Z.; Tian, J.; Li, J.; Liu, Y.; Li, Q. Electrical conductivity of $\left(\mathrm{Na}_{3} \mathrm{AlF}_{6}-40\right.$ wt.\%K $\left.\mathrm{AlF}_{6}\right)-\mathrm{AlF}_{3}$ melts. J. Cent. South. Univ. 2008, 15, 819-823. [CrossRef]

17. Yang, J.; Li, W.; Yan, H.; Liu, D. Conductivity of KF-NaF-AlF 3 system low-temperature electrolyte. In Light Metals; Sadler, B.A., Ed.; Springer: Berlin, Germany, 2013; pp. 689-693.

18. Chrenkova, M.; Danek, V.; Silny, A.; Utigard, T. Density, Electrical Conductivity and Viscosity of Low Melting Baths for Aluminum Electrolysis, Proceedings of the 125th TMS Annual Meeting, Anaheim, CA, USA, 4-8 February 1996; Hale, W., Ed.; TMS: Warrendale, PA, USA, 1996; pp. 227-232.

19. Fellner, P.; Kobbeltvedt, O.; Sterten, A.; Thonstad, J. Electrical conductivity of molten cryolite-based binary mixtures obtained with a tube-type tell made of pyrolytic boron nitride. Electrochem. Acta 1993, 38, 589-592. [CrossRef]

20. Wang, X.; Peterson, R.D.; Tabereaux, T. A Multiple Regression Equation for the Electrical Conductivity of Cryolite Melts, Proceedings of the 122nd TMS Annual Meeting, Denver, CO, USA, 21-25 February 1993; Das, S.K., Ed.; TMS: Warrendale, PA, USA, 1993; pp. 247-255.

21. Redkin, A.A.; Tkacheva, O.Y.; Shuryghin, A.P. Electrical Conductivity of Molten Electrolytes for Light Metal Production, Proceedings of the 137th TMS Annual Meeting, New Orleans, LO, USA, 9-13 March 2008; DeYoung, D.H., Ed.; Wiley: Chichester, UK, 2008; pp. 505-508.

22. Solheim, A.; Rolseth, S.; Skybakmoen, E. Liquidus temperatures for primary crystallization of cryolite in molten salt systems of interest for aluminum electrolysis. Metall. Mater. Trans. B 1996, 27B, 739-745. [CrossRef]

23. Híveš, J.; Fellner, P.; Thonstad, J. Transport numbers in the molten system NaF-KF- $\mathrm{AlF}_{3}-\mathrm{Al}_{2} \mathrm{O}_{3}$. Ionics 2013, 19, 315-319. [CrossRef]

24. Grjotheim, K.; Krohn, C.; Malinovsky, M.; Matiasovsky, K.; Thonstad, J. Aluminium Electrolysis. Fundamentals of the Hall-Heroult Process, 2nd ed.; Aluminium-Verlag: Dusseldorf, Germany, 1982; 443p.

25. Kubinakova, E.; Danielik, V.; Hives, J. Electrical conductivity of low-temperature cryolite electrolytes with high addition of aluminum fluoride. JES 2017, 164, E265-E269. [CrossRef]

26. Rolin, M. Conductivite electrique des melanges a base de cryolithe fondue: Systemes $\mathrm{NaF}-\mathrm{AlF}_{3}, \mathrm{AlF}_{6} \mathrm{Na}_{3}-\mathrm{Al}_{2} \mathrm{O}_{3}$ et $\mathrm{AlF}_{6} \mathrm{Na}_{3}-\mathrm{CaF}_{2}$. Electrochim. Acta 1972, 77, 2293-2307. [CrossRef] 
27. Parker, S.F.; Ramirez-Cuesta, A.J.; Daemen, L.L. The structure and vibrational spectroscopy of cryolite, $\mathrm{Na}_{3} \mathrm{AlF}_{6} \cdot \mathrm{RSC} A d v .2020$, 10, 25856-25863. [CrossRef]

28. Lacassagne, V.; Bessada, C.; Florian, P.; Bouvet, S.; Ollivier, B.; Coutures, J.-P.; Massiot, D. Structure of high-temperature $\mathrm{NaF}-\mathrm{AlF}_{3}-\mathrm{Al}_{2} \mathrm{O}_{3}$ Melts: A multinuclear NMR study. J. Phys. Chem. B 2002, 106, 1862-1868. [CrossRef]

29. Frenkel, J. Kinetic Theory of Liquids; Dover Publications: Mineola, NY, USA, 1955; 488p.

30. Lyutina, A.S.; Kataev, A.A.; Rudenko, A.V.; Tkacheva, O.Y. Effect of $\mathrm{Al}_{2} \mathrm{O}_{3}$ and $\mathrm{CaF}_{2}$ additives on the viscosity of conventional cryolite melts. Chim. Techno Acta 2021, 8, 20218306. [CrossRef]

31. Tkacheva, O.; Arkhipov, P.; Kataev, A.; Rudenko, A.; Zaykov, Y. Electrolyte viscosity and solid phase formation during aluminium electrolysis. Electrochem. Commun. 2021, 122, 106893. [CrossRef] 